\title{
A BASIN FACILITY FOR EXAMINING IRRADIATED NUCLEAR FUEL
}

\author{
F. C. Locke
}

SRL

RECORD COPY

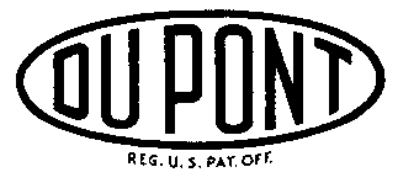

Savannah River Laboratory

Aiken, South Carolina 


\section{LEGAL NOTICE}

This report was prepared as an account of Government sponsored work. Neither the United States, nor the Commission, nor any person acting on behalf of the Commlssion:

A. Makes any warranty or representation, expressed or implied, with respect to the accuracy, completeness, or usefulness of the information contained in this report, or that the use of any information, apparatus, method, or process disclosed in this report may not infringe privately owned rights; or

B. Assumes any llabilities with respect to the use of, or for damages resulting from the use of any information, apparatus, method, or process disclosed in this report.

As used in the above, "person acting on behalf of the Commission" includes any employee or contractor of the Commission, or employee of such contractor, to the extent that such employee or contractor of the Commission, or employee of euch contractor prepares, disseminates, or provides accese to, any Information pursuant to his employment or contract with the Commission, or his employment with such contractor.

Printed in USA. Price $\$ 2.00$

Avallable from the Clearinghouse for Federal Sclentiflc and Technical Information, National Bureau of Standards, U. S. Department of Commerce, Springfield, Virginia 


\title{
A BASIN FACILILITY FOR EXAMINING IRRADIATED NUCLEAR FUEL
}

\author{
by \\ Frederick C. Locke
}

Approved by

玉. C. Nelson, Research Manager

Pile Engineering Division

$$
\text { October } 1964
$$

E. I. DU PONT DE NEMOURS \& COMPANY

SAVANNAH RIVER LABORATORY

AIKEN, SOUTH CAROLINA

CONTRACT AT(07.2).1 WITH THE

UNITED STATES ATOMIC ENERGY COMMISSION 


\section{ABSTRACT}

The SRL Room of the Receiving Basin for off-Site Fuels facility at the Savannah River Plant provides equipment for disassembling and inspecting irradiated nuclear fuels in two water-filled basins. The Disassembly Basin is used for horizontal disassembly of sound or failed fuel assemblies and for cutting and other operations that expose bare fuel to the basin water. The Inspection Basin has equipment for vertically disassembling and nondestructively examining fuel elements. Contamination of the deionized basin water is controlled by a purge flow that can be pumped to either of three disposal systems according to the water activity. 


\section{CONTENTS}

$\underline{\text { Page }}$

List of Figures... . . . . . . . . . 6

Introduction . . . . . . . . . . . . . . . 7

General Description of SRL Room . . . . . . . . 8

Disassembly Basin . . . . . . . . . . . 8

Inspection Basin. . . . . . . . . . . . 8

Basin Construction . . . . . . . . . . . 8

Basin Doors . . . . . . . . . . . . . . . . 9

Specifications for Underwater Equipment . . . . . . 10

Disassembly Basin Equipment . . . . . . . . . . 10

Horizontal Disassembly Machine . . . . . . . 10

Hopper . . . . . . . . . . . . . . 12

Tube Cutter ................. 12

Slitting saw . . . . . . . . . . . . . 13

Cradle . . . . . . . . . . . . . . 14

Other Equipment . . . . . . . . . . . . . 15

Inspection Basin Equipment . . . . . . . . . . 15

Vertical Disassembly Equipment . . . . . . . . 15

Tipping Beam . . . . . . . . . . . . . . . 15

Measuring Machines . . . . . . . . . . . 16

Horizontal Measuring Machine . . . . . . 16

Vertical Measuring Machine . . . . . . . 16

Periscope . . . . . . . . . . . . . 18

Auxiliary Equipment. . . . . . . . . . . . 19

Underwater Lamps . . . . . . . . . . . . 19

Monorails . . . . . . . . . . . . 20

Radiation and Contamination Control. . . . . . . 20

Bibliography. . . . . . . . . . . . . . . 23 


\section{LIST OF FIGURES}

Figure

$\underline{\text { Page }}$

1 Arrangement of SRL Room . . . . . . . . 9

2 Horizontal Disassembly Machine ....... 11

3 Tube Cutter............. 12

4 Underwater Slitting Saw ......... 13

5 Cradle and Fuel Support Channel ...... 14

6 Horizontal and Vertical Measuring Machines . 17

7 Periscope in Inspection Basin. . . . . 18

8 Underwater Lamp . . . . . . . . . 19

9 Basin Water Circulating Pump . . . . . . 21 


\section{A BASIN FACILITY FOR EXAMINING IRRADIATED NUCLEAR FUEL}

\section{INTRODUCTION}

The SRL Room is part of the Receiving Basin for offSite Fuels (RBOF) facility at the Savannah River Plant. (1,2) In addition to the SRL Room, RBOF has facilities for:

- Receiving shielded shipping casks that arrive via truck or rail.

- Cleaning and flushing these casks.

- Removing the irradiated reactor fuel from the casks in a water-filled basin.

- Storing the fuel underwater for indefinite periods.

- Repackaging the fuel if necessary for shipment to a processing plant.

The background developed within the Savannah River Laboratory (SRL) from several years of experience with underwater handling and examination of irradiated fuel pieces provided an abundance of information from which specifications were established for the layout of the SRL Room and the conceptual design of the major equipment components.

The SRI Room is being used for routine examination of fuel assemblies from the Heavy Water Components Test Reactor (HWCTR), which is at the Savannah River Plant. Experimental assemblies are removed from the reactor at intervals during their irradiation and are sent to the SRL Room where they are disassembled, measured, visually inspected, photographed, and reassembled for further irradiation if their condition permits. At the completion of each test irradiation, the fuel assembly is given a complete nondestructive examination to determine the extent of physical changes during irradiation. Then, samples may be cut from the fuel for shipment to the High Level Caves at SRI for chemical and metallographic studies.

Fuel assemblies that fail during irradiation are taken apart and examined as the first step in the task of deter- 
mining the location and cause of fallure. The ensuing steps may involve detailed examination of the fallure in the High Level Caves, or canning of the failure for storage and eventual disposal if additional study is not warranted.

\section{GENERAL DESCRIPTION OF SRL ROOM}

The SRL Room (Figure 1) has two basins, each equipped for a particular category of underwater work: the Disassembly Basin and the Inspection Basin. The basins are connected to each other and to the remainder of the RBOF facillty by canals.

\section{Disassembly Basin}

The Disassembly Basin is used for horizontal disassembly of sound or falled fuel, for cutting fuel elements into short lengths for samples or disposal, and for operations that expose bare fuel to the basin water, for example, puncturing the cladding of oxide fuel elements to measure the internal gas pressure. The basin is 40 feet long, 5 feet wide, and 14 feet deep with a centrally located sump 6 feet long and 4 feet wide and extending to the -19 foot elevation.

\section{Inspection Basin}

The Inspection Basin contains equipment for the nondestructive examination of fuel elements. The basin is 30 feet long, 5 feet wide, and 14 feet deep, except for the 10 feet nearest the entrance door, where the depth is increased to 29 feet. In the center of the 29 foot depth, a hole 3 feet in diameter extends to the -44 foot elevation.

\section{Basin Construction}

The canals and basins are made of ordinary concrete about 3 feet thick at all points except at the east end of the Inspection Basin where additional thickness was provided as a foundation for the future installation of a shielded cubicle or dry cave. To prevent the leaching of concrete by the deionized water, the canal walls and floor are coated with a waterproof paint and the two basins are lined with stainless steel, which provides high resistance to damage both by mechanical impact and by radiation. The lining on the walls is 11 gage sheet, and the floors are covered with 3/8-inch plate. 


\section{Basin Doors}

The basins can be isolated from the canal system by watertight swinging doors that extend from just above the water surface to the bottom of the basins. Both doors have an 8-inch-diameter gate valve at the -13 foot elevation through which fuel elements and other objects can be moved when contamination of the basin water makes opening the doors undesirable.

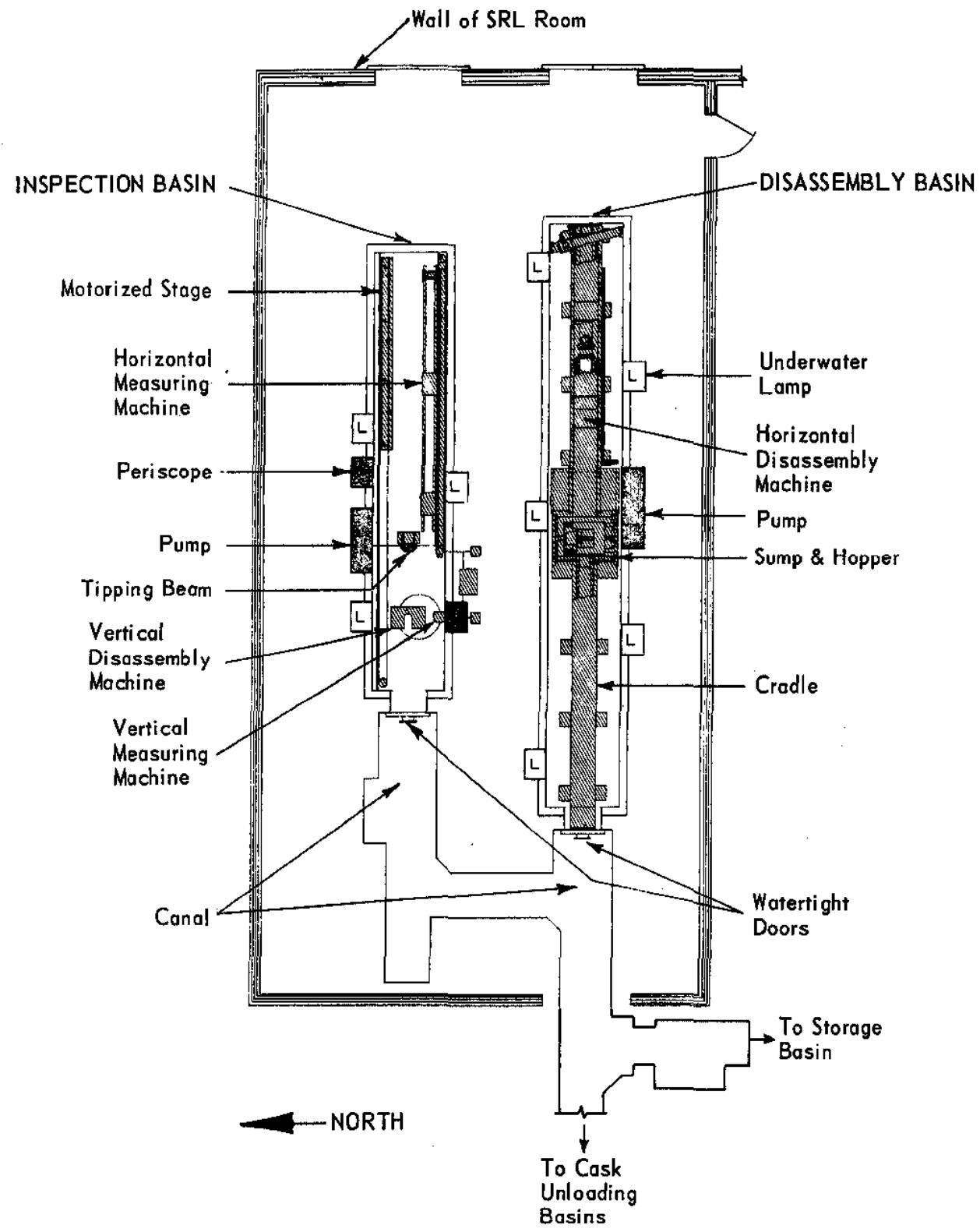

FIG. I ARRANGEMENT OF SRL ROOM 


\section{SPECIFICATIONS FOR UNDERWATER EQUIPMENT}

All underwater equipment was built to operate for indefinite periods with a minimum of maintenance. It is built of materials that are resistant both to damage by intense and prolonged radiation and to corrosion by delonized water. The main structural members are type 304 stainless steel; bearings are bronze, brass, or stainless steel; and smaller pieces of equipment that must be handled manually are aluminum. Because it was not intended that the water be drained from the basins for equipment repair, all moving parts, such as shafts, bearings, chains, and gearboxes, were designed to be removable from the machines with simple remote tools. Also, the entire machines can be remotely removed from the basins should replacement become necessary.

All disassembly and inspection equipment can accommodate reactor fuel assemblies or components 16 feet long and up to 6 inches in diameter. Assemblies up to 10 inches square can be handled with minor machine modifications.

\section{DISASSEMBLY BASIN EQUIPMENT}

The Disassembly Basin contains the following equipment:

- Horizontal Disassembly Machine, the major piece of equipment in the basin. This machine is designed to perform the basic functions of pulling, pushing, and rotating fuel assemblies.

- A hopper for collecting radoactive chips and other debris.

- A cutter for reducing tubular fuel elements into short lengths with a minimum of chip formation.

- A saw for making longitudinal or circumferential cuts in fuel housings or hardware.

- A cradle for supporting long fuel assemblies during cutting or disassembly.

\section{Horizontal Disassembly Machine}

The horizontal disassembly machine has a stainless steel frame nineteen feet long, which supports a movable carriage and drive mechanism (Figure 2). The frame, which is bolted to the floor of the basin, will withstand a force 
of 20,000 pounds applied between any two points on the centerline of the carriage. It has longitudinal rails on each side that guide the carriage and support the chains that drive the carriage. The frame also carries the chain sprocket shafts, and has a fixture at one end to accommodate brackets against which fuel housing tubes are butted during the removal of the fuel pieces.

The carriage, which travels the full length of the frame, is attached to two 1-inch-pitch roller chains, which are driven by a hydraulic motor through a gear reducer. On the carriage is a second gear reducer on which is mounted a special chuck for gripping long fuel tubes that are to be rotated for cutting. On an adapter at the front of the carriage, various attachments can be mounted for pushing and pulling on elements. The carriage can travel at speeds varying from one to ten feet/minute, and it can exert a controlled force of up to 4,000 pounds in either direction of travel.

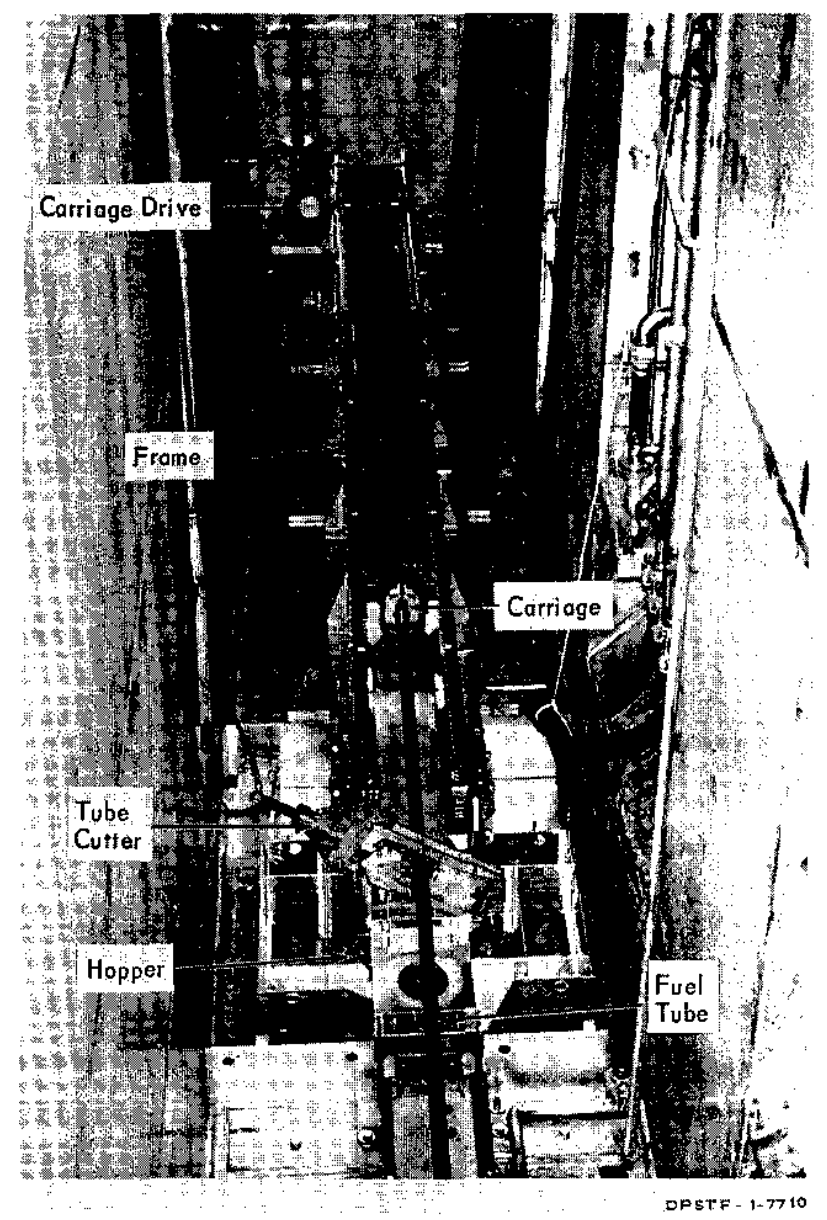

FIG. 2 HORIZONTAL DISASSEMBLY MACHINE

View Looking East in Disassembly Basin 
Hopper

The sump at the center of the Disassembly Basin contains a hopper about four feet square and three feet deep, which is under one end of the disassembly machine. The hopper serves as a collection point for radioactive debris from the disassembly of failed fuel elements and for fragments or chips produced in fuel cutting operations. To prevent the spread of radioactivity to the bulk of the basin water during. disassembly or cutting, radioactive particles are entrained in the purge flow that is pumped from the basin, through a 20-mesh screen in the bottom of the hopper, and to the waste disposal system (see "Radiation and Contamination Control"). Fixtures are attached to a frame at the top of the hopper to hold a slitting saw or a tube cutter.

\section{Tube Cutter}

The tube cutter (Figure 3) is an improved model of a similar machine described in a previous report. (3) It has two fixed cutter wheels and a movable cutter wheel driven by a hydraulic ram. A tube to be cut is placed in the cutter as shown in Figure 3, pressure is applied to the movable cutter wheel, and the tube is rotated by the chuck on the carriage of the disassembly machine. The cut pieces are placec in cans for shipment or disposal.

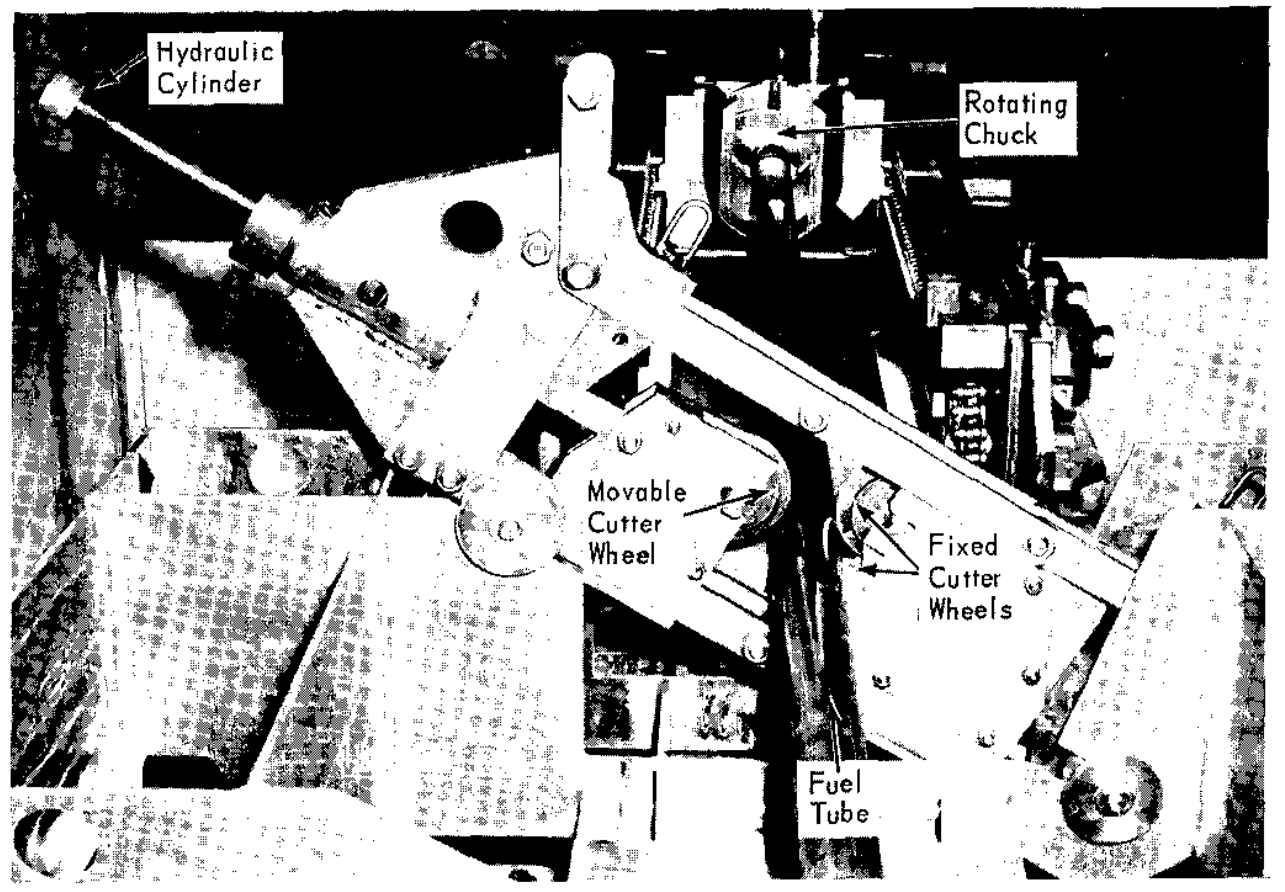

FIG. 3 TUBE CUTTER 


\section{Slitting Saw}

The slitting saw (Figure 4) was developed primarily for cutting Zircaloy housing tubes. The circular blade is eight inches in diameter and powered by a two-horsepower, submersible motor that operates through a worm gear reducer. This blade will cut to a depth of $1 / 4$ inch in Zircaloy. The saw is mounted over the hopper on an adjustable table that moves at right angles to the axis of the disassembly machine. Two mounting positions on the table allow the saw to be placed for either longitudinal or transverse cutting. The piece to be cut is clamped to the carriage and either driven axially or rotated at the optimum cutting speed for the saw.

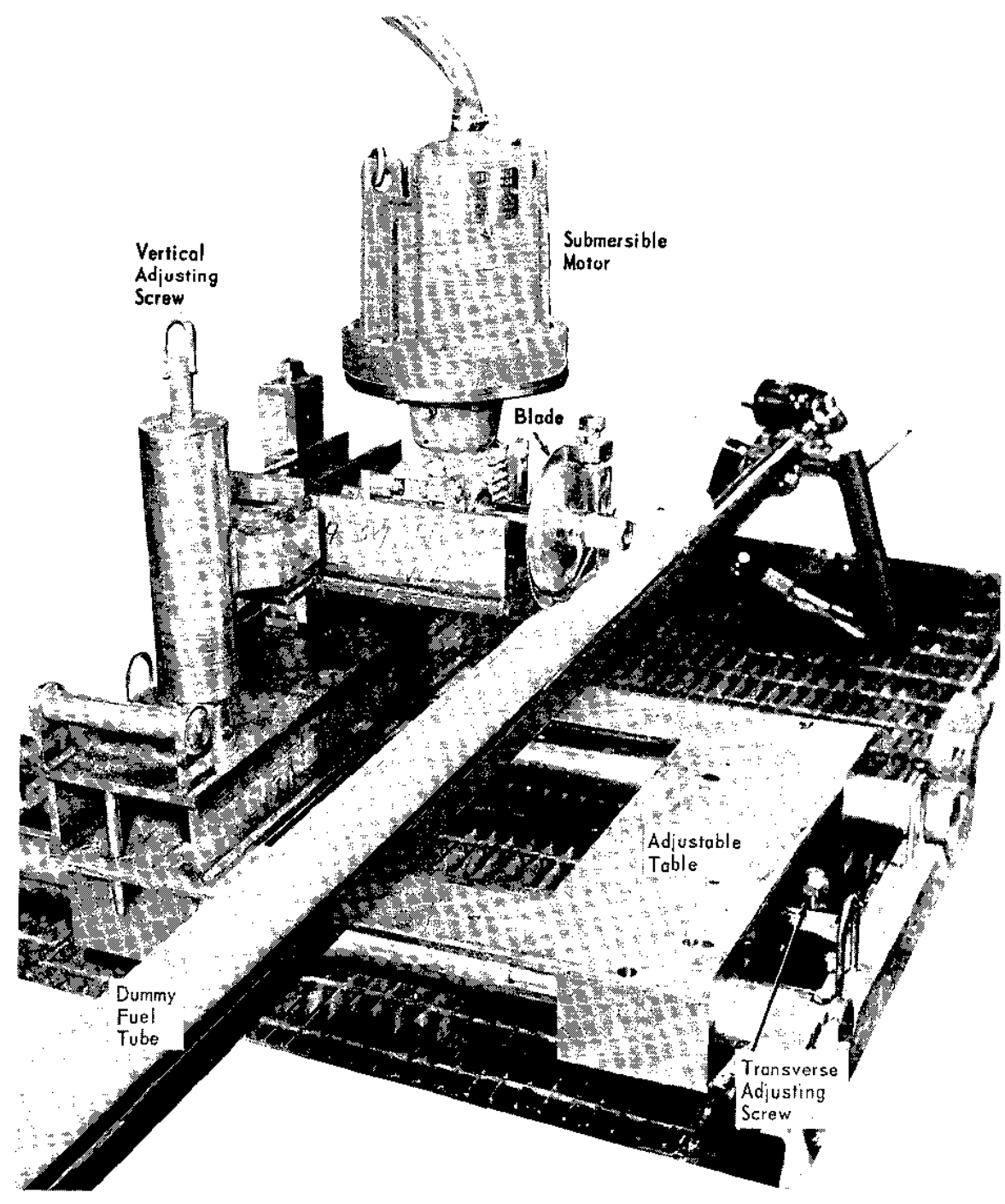

FIG. 4 UNDERWATER SLITTING SAW 
A framework similar in structure to the frame of the disassembly machine extends from the hopper to the watertight door that separates the basin from the canal (Figure 5). Designated the cradle, this framework provides an extension of the longitudinal rails of the disassembly machine so that a wheeled channel, which supports horizontal fuel elements, may be moved down the length of the basin to any position that is necessary for a particular operation.

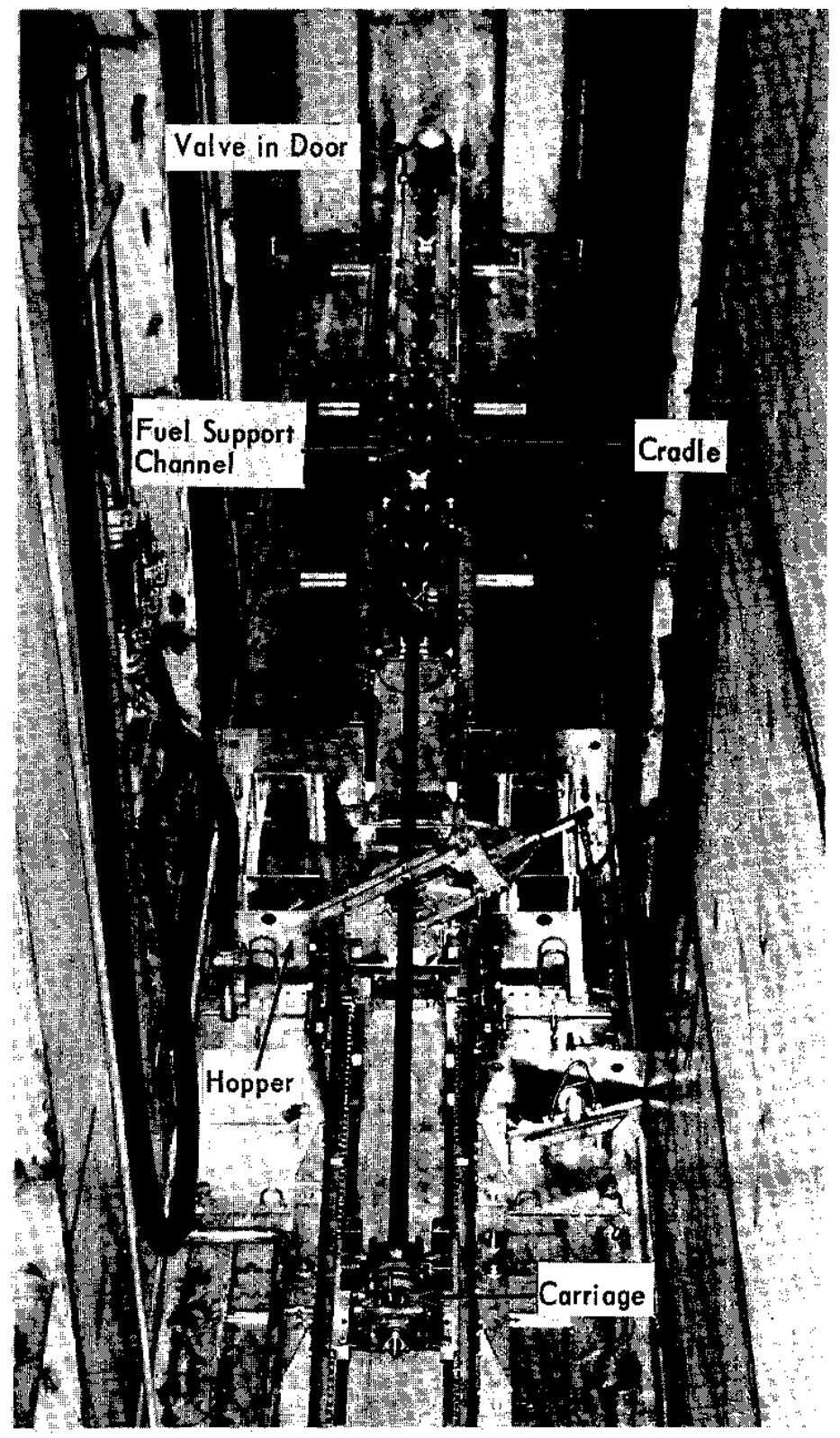

FIG. 5 CRADLE AND FUEL SUPPORT CHANNEL

View Looking West in Disassembly Basin 
Equipment for puncturing the cladding and measuring the internal gas pressure of irradiated uranlum oxide fuel elements is being fabricated and will be installed in the Disassembly Basin.

\section{INSPECTION BASIN EQUIPMENT}

The Inspection Basin contains the following equipment:

- Vertical disassembly equipment.

- Tipping beam for moving long elements from a vertical to a horizontal position.

- Measuring machines.

- Periscope and movable stages.

\section{Vertical Disassembly Equipment}

The deeper section of the Inspection Basin allows a fuel assembly as long as 16 feet to be brought into the basin in a vertical position with at least 10 feet of water above the assembly for shielding. Over the 44-foot-deep hole in the deeper section of the basin is mounted the equipment for vertical disassembly of nested tubular fuel assemblies. For disassembly, the upper end of the fuel assembly housing is locked into a carrier plate that is suspended from a twin line hoist above the deep hole. The carrier plate and fuel assembly are lowered to the -29 foot elevation, where the plate is latched to a clamping mechanism to hold the housing in a vertical position while the fuel pieces are withdrawn with a special gripper on a chain fall.

\section{Tipping Beam}

Long fuel pieces or complete fuel assemblies may be rotated from the vertical to the horlzontal position on the tipping beam that pivots over the edge of the basin floor between the 14 and 29 foot depths. A vertical fuel assembly is placed in the beam so that the weight of the assembly is supported on a projecting foot at the lower end of the beam. This end of the beam is then lifted by means of a manually operated chain fall until the assembly is horizontal at the 14 foot depth. Fuel pieces may then be moved from the horizontal tipping beam to any of the other pieces of inspection equipment that are located at the 14 foot depth. 


\section{Measuring Machines}

Two measuring machines are in the Inspection Basin (Figure 6) for determining outside and inside diameters, lengths, and bow of fuel pieces. The machines have sensing heads that contain one or more linear variable differential transformers coupled to a strip chart recorder; the sensing heads operate by a principle described previously. (4)

Horizontal Measuring Machine. The horizontal measuring machine was designed for measuring outside diameters and bow of both long and short fuel elements. It has a chuck and a tailstock that support the fuel piece in a fixed horizontal position. The sensing head is mounted on a carriage, which is propelled along the element by a roller chain drive. On the sensing head are three differential transformers, two of which bear on opposite sides of the fuel element to measure the outer diameter, width, or thickness depending upon the geometry of the fuel piece. The third transformer bears on a straightedge that is parallel to the long axis of the element. The straightedge provides a zero reference when this transformer is coupled with one of the transformers on the element to indicate bow. Switching of the transformer connections for measuring either outer diameter or bow is done at the recorder. The chart drive is coupled to the roller chain drive that moves the carriage to provide a correlation between the chart motion and the movement of the sensing head. Circumferential traces of the outside diameters of a fuel tube can be made by stopping the carriage at the desired location and rotating the tube. In this case, the recorder is driven by an internal motor.

Vertical Measuring Machine. The vertical measuring machine was designed to measure the inside diameters of fuel tubes or to support a borescope for viewing the inner surfaces. The machine is mounted on the wall of the Inspection Basin above the 44-foot-deep hole. A fuel piece to be measured is hung in a carrier that moves on vertical tracks. The sensing head, which contains differential transformers for measuring inside diameters, is mounted on the lower end of a probe that is about 20 feet long. The probe is fixed in position on the measuring machine, and the fuel piece is raised or lowered by a roller chain drive that is attached to the carrier to produce a longitudinal trace of the tube inside diameter. The roller chain drive is coupled to the same chart drive as the horizontal measuring machine. A circumferential trace can be made by stopping the fuel piece at a given elevation and rotating the probe within the bore of the fuel. The bore of the moving fuel piece can be viewed with a borescope that is interchangeable with the measuring probe. 


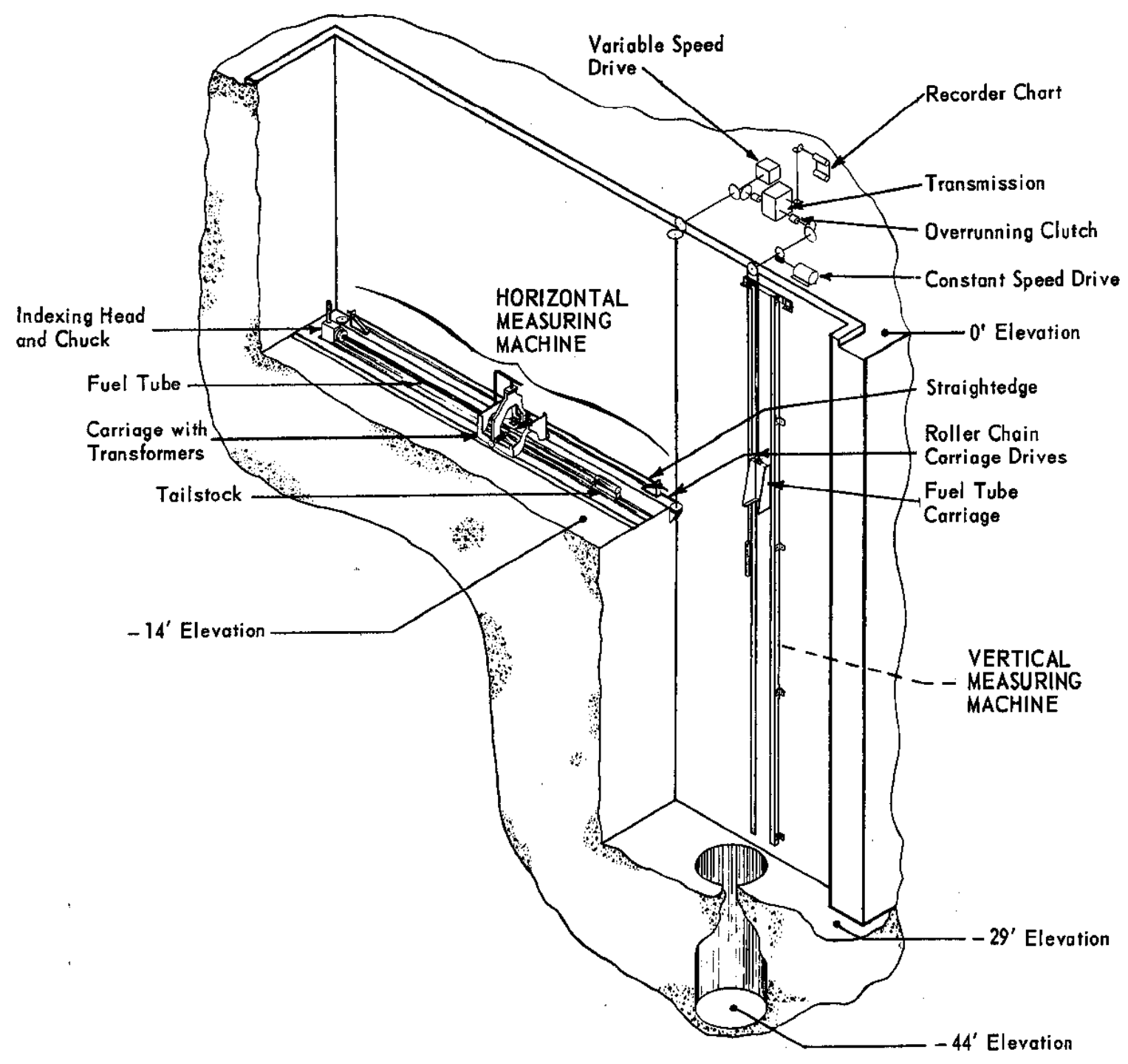

FIG. 6 HORIZONTAL AND VERTICAL MEASURING MACHINES 


\section{Periscope}

A periscope (Figure 7) designed and built at SRL is mounted in a recess in the wall of the Inspection Basin. The details of the periscope and its advantages are described in a separate report. (5) Iong objects such as fuel tubes and... housings are positioned in front of the periscope by a motor-driven stage, which travels the length of the basin on horizontal tracks. Rollers are positioned on the stage to support the fuel piece so that by a combination of rotary and longitudinal movement the entire surface can be scanned. Small objects can be positioned in front of the periscope on a fixed stage, which can be rotated manually about two axes.

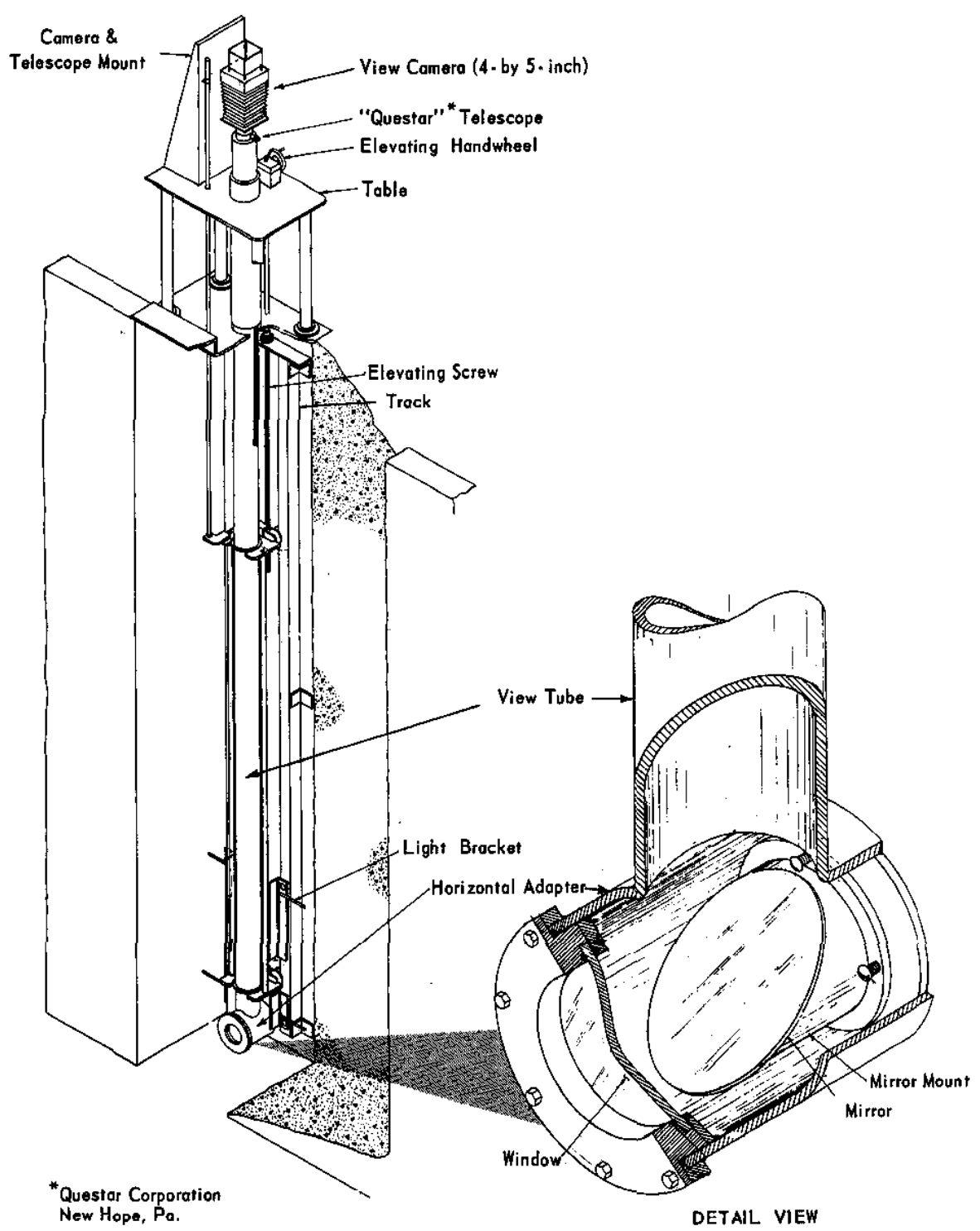

FIG. 7 PERISCOPE IN INSPECTION BASIN 


\section{AUXILIARY EQUIPMENT}

\section{Underwater Lamps}

The basins are lighted by underwater mercury vapor lamps (Figure 8), which are recessed in the walls. The Disassembly Basin has five, and the Inspection Basin has four of these lamps in especially designed fixtures suspended about eight feet below the surface of the water. The lamps are phosphor coated to improve color definition, and their rated output is 59,000 lumens. The reflecting fixtures have glass front covers that are sealed to the reflector bodies to prevent spillage of mercury in case of accidental lamp breakage. Each lamp gives illumination of from 250 to 300 foot-candles on the basin floor.

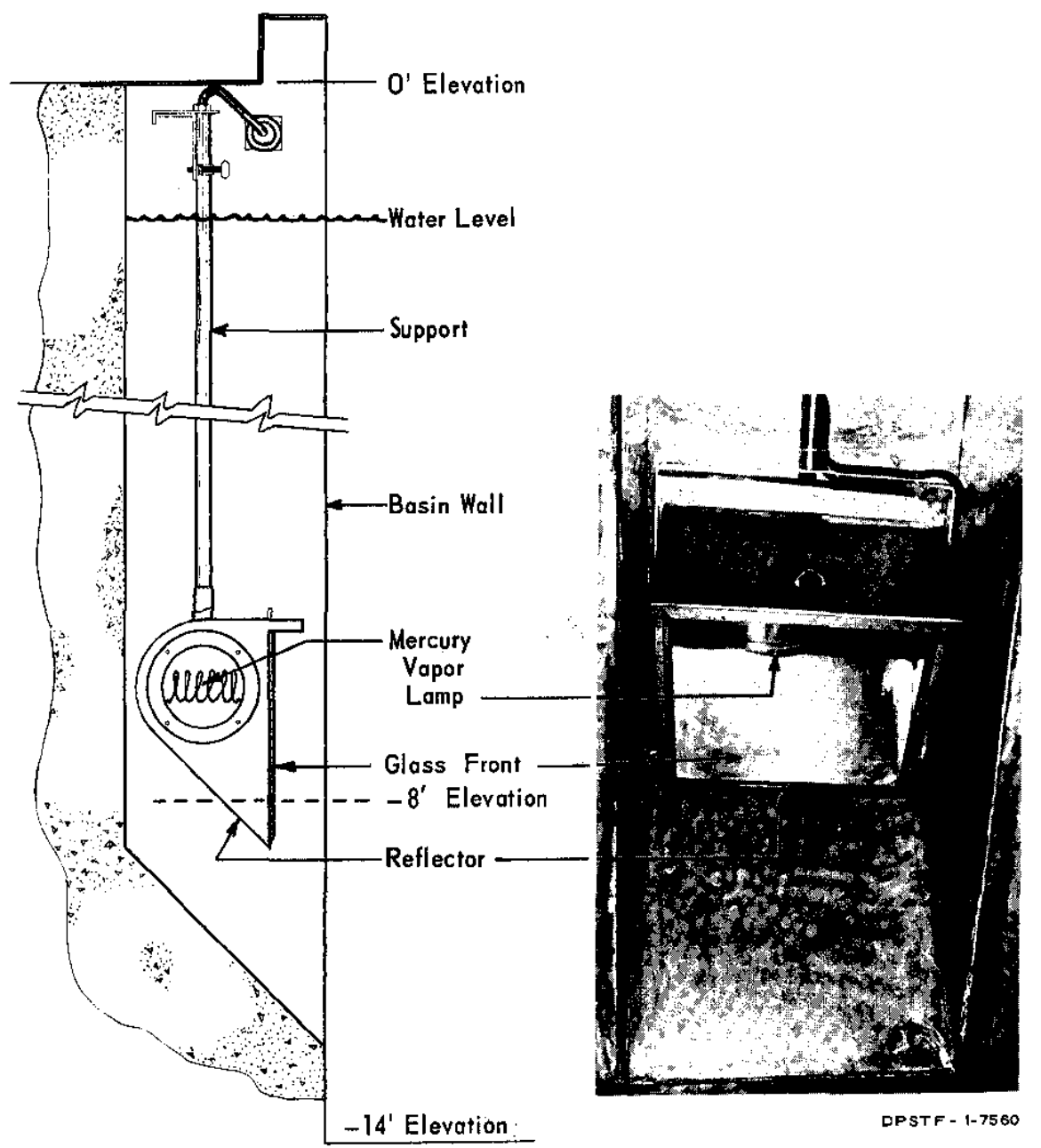

a. Section Through Recess in Basin Wall

b. View of Lamp Fixture at -8 ' Elevation

FIG. 8 UNDERWATER LAMP 


\section{Monorails}

Fuel elements and other heavy objects are moved and positioned in the canals and basins with manual or electric hoists on an overhead monorail system, which has a capacity of 1000 pounds/foot. In addition to the main monorails over the center of the basins and canals, there are two lighter monorails six inches inside the basin walls and at the same elevation as the main rall. These auxiliary rails do not connect with the main rail, and were provided to allow exact placement of heavy assemblies and equipment on the basin floors.

\section{RADIATION AND CONTAMINATION CONTROL}

Experience with failed fuel assemblies in other basins at the Savannah River Plant has shown that basin water activity must be less than $5 \times 10^{-5}$ curie/ml to prevent spread of contamination to the air above the basins and to the surrounding areas and to limit radiation levels in the working areas around the basins. The water activity should be maintained near $5 \times 10^{-10}$ curie/ml for the most economical disposal of the purge flow.

A circulating pump (Figure 9) is installed in each of the basins and in the canal to control dissolved and particulate contamination in the water. Hoses, which may be connected to a manifold on each pump suction, allow a continuous purge flow to be drawn from selected points in the basins, for example, through the hopper of the disassembly machine or through a skimmer from the water surface, and to be discharged at rates of from 3 to $75 \mathrm{gpm}$ to the disposal system. Screen filters in the pump suction lines prevent the entry of large particles that might damage the impellers.

The level of the basin water is kept within $\pm 1 / 2$ inch of the desired elevation by automatic control valves in the supply lines. During normal disassembly and inspection operations, a flow of about $6 \mathrm{gpm}$ through a basin is sufficient to maintain water clarity and keep water activity below $5 \times 10^{-11}$ curies $/ \mathrm{ml}$.

Contaminated water discharged from the basins is sent to one of three disposal systems depending on its specific activity: low activity water $\left(<5 \times 10^{-10}\right.$ curie $\left./ \mathrm{ml}\right)$ is sent to a seepage basin that has a capacity of $200 \mathrm{gpm}$; intermediate activity water $\left(5 \times 10^{-20}\right.$ to $5 \times 10^{-8}$ curie $\left./ \mathrm{ml}\right)$ is recirculated through a filter-deionizer system and retumed to the basin as make-up; and high activity water $\left(>5 \times 10^{-8}\right.$ curie $\left./ \mathrm{ml}\right)$ is 
sent to underground waste storage tanks where it is concentrated by a steam evaporator. The immediate availability of these three systems allows maximum economy and flexibility in disposal of waste water.

The shielding and arrangement of piping and equipment is such that if a mishap should release up to $10^{6}$ curies of radioactive material in a basin, the water in that basin could be flushed to the waste tanks by displacement with clean water without exposing personnel to radiation exceeding $5 \mathrm{r} / \mathrm{hr}$ and without exceeding an accumulated dose of $1 \mathrm{r}$ for any individual.

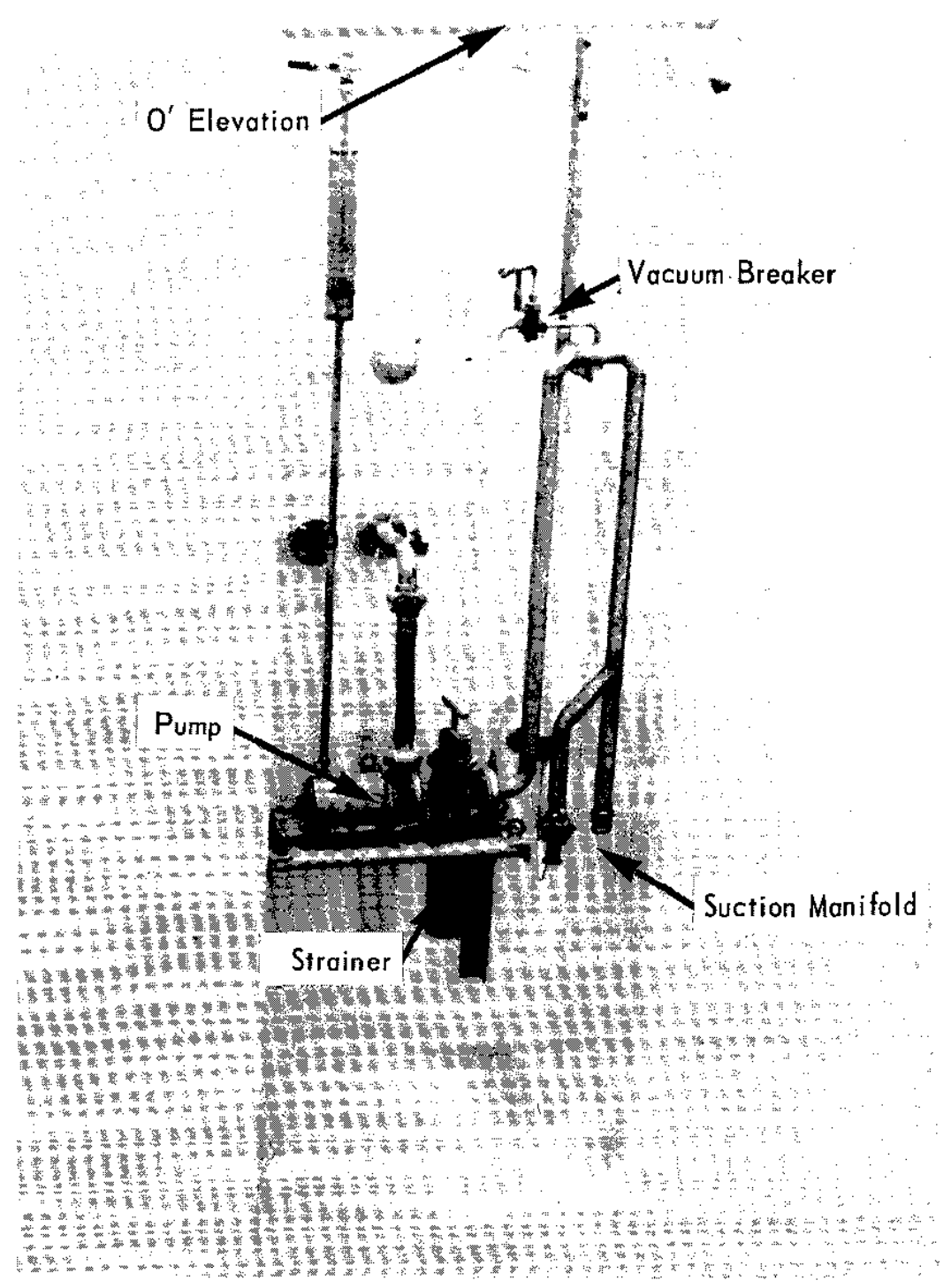

DPSTF - 1- 7144

FIG. 9 BASIN WATER CIRCULATING PUMP 
The air in the SRI Room is kept at a lower pressure than that of the atmosphere and of the rest of the RBOF building. Air is exhausted from the room by a once-through system that removes aix from the basin areas at floor level. The air passes through absolute filters and is discharged to the atmosphere via a stack. An overhead exhaust duct between the two basins can be fitted with large flexible ducts, which provide a method for quickly collecting radioactive gas that might be released during cutting of fuel elements. 


\section{BIBLIOGRAPHY}

1. Smiley, S. D., J.W. Langhaar, and R. Maher. "Shipping and Storing Power Fuels Prior to Reprocessing." Paper presented at Nuclear Engineering Congress, February 1962.

2. Owen, J. H. Processing of Power Reactor Fuels, Nineteenth Quarterly Progress Report - April 1 to July l, 196?. E. I. du Pont de Nemours \& Co., Savannah River Laboratory, Aiken, S. C. USAEC Report DP-782 (1962).

3. Locke, F. C. A Remotely Operable Cutter for Irradiated Metallic-Uranium Tubes. E. I. du Pont de Nemours \& Co., Savannah River Laboratory, Aiken, S. C. USAEC Report DP -563 ( 1961 ).

4. Goodwin, L. E. A Differential Transformer Gauge for Outside and Inside Diameters of Long Tubes. E. I. du Pont de Nemours \& Co., Savannah River Laboratory, Aiken, S. C. USAEC Report DP-263 (1958).

5. Locke, F. C. A Periscope for Viewing and Photographing Radioactive objects Underwater. E. I. du Pont de Nemours \& Co., Savannah River Laboratory, Aiken, S. C. USAEC Report DP-931 (1964). 